\title{
COVID-19 ASSOCIATED MORTALITY - FROM THE FIRST CASE TO THE LATEST AVAILABLE DATA ${ }^{1}$
}

\author{
Irina PahomiiC)2, Ph.D. student, scientific researcher, \\ National Institute for Economic Research, Centre for Demographic Research, \\ Chisinau, Moldova \\ Charles University, Faculty of Science, Department of Demography and \\ Geodemography, Prague, Czechia \\ DOI: https://doi.org/10.36004/nier.cdr.2021.15-10
}

\begin{abstract}
Rezumat: Acest studiu are drept scop prezentarea unei imagini de ansamblu asupra mortalității asociate cu Covid-19 la nivel național și subnațional. Distribuția pe sexe a deceselor cauzate de Covid-19 este în principiu aceeași la nivel național și subnațional. Astfel, aproximativ jumătate din toate decesele pozitive cauzate de Covid-19 revin femeilor, iar jumătate bărbaților. Rata de fatalitate la nivel national este de 22,8 decese la 1.000 de cazuri de infecție. Analiza abordează și subiectul mortalității premature. Astfel, 52,8\% din totalul deceselor în rândul femeilor s-au concentrat până la vârsta de 70 de ani, în timp ce în rândul bărbaților, ponderea deceselor premature cauzate de Covid-19 este de 56\%. Analiza subnațională relevă unele discrepanțe pe acest subiect. Chișinăul a înregistrat cel mai redus nivel de mortalitate prematură din totalul mortalității asociate cu Covid-19 observate. Analiza sistematică și continuă a mortalității asociate cu Covid-19 rămâne crucială în dezvoltarea politicilor și măsurilor eficiente de protectie.
\end{abstract}

Abstract: This study aims to present an overview of Covid-19 associated mortality at the national and sub-national levels. The sex distribution of Covid-19 deaths is mainly the same at national and sub-national levels. Thus, about half of all positive deaths from Covid-19 are in females, and half are in males. The national case fatality rate is about 22.8 deaths per 1,000 cases of infection. The analysis also addresses the subject of premature mortality. Thus, $52.8 \%$ of all deaths among women were concentrated up to the age of 70, while among men, the share of premature Covid-19 deaths is 56\%. The subnational analysis reveals some discrepancies in this area. Chisinau recorded the lowest percentage of premature mortality in the total observed Covid-19 associated mortality. Systematic and continuous analysis of Covid-19 associated mortality remains crucial in developing effective protection policies and measures.

Key-words: Covid-19, national/subnational level, premature mortality.

JEL Classification: I1, I14.

\section{Introduction}

The covid-19 pandemic affected all world and led to a significant number of infections and untimely deaths. This pandemic has affected all socioeconomic areas and led to unprecedented protection measures, such as national/international lockdowns and quarantines. This pandemic took everyone by surprise, and not every country could come in time with an adequate response. Moldova is one of the countries that, despite its efforts,

\footnotetext{
${ }^{1}$ Articolul este elaborat în cadrul Programului de Stat (2020-2023) 20.80009.0807.21

"Migrația, schimbări demografice și politici de stabilizare a situației".

2 (C) Pahomii Irina, braga.pahomiiirina@gmail.com
} 
lags behind. It is important to note that the success or failure of a country is determined by a multitude of factors, starting with the economic situation of the country and ending with access to quality medical services and medicines.

One of the most important aspects is the number of deaths caused by Covid-19 and the case fatality rate. Thus, data on Covid-19 associated mortality and their systematic research are becoming of major importance.

This study aims to present an overview of Covid-19 associated mortality at the national and sub-national levels.

The actuality of this research is determined by the high importance of understanding and presenting an updated picture of the current situation.

The impact of the Covid-19 pandemic on the level and structure of mortality is indisputable, and its impact will last in the coming years. This is another argument in need to study mortality associated with Covid-19.

\section{Literature review}

Due to the great importance of the research of Covid-19 associated mortality, there is a large amount of literature that analyses different aspects, starting from some medical aspects and ending with some socio-economic discrepancies and risk factors.

The discrepancies in Covid-19 associated mortality by sexes are highlighted in many research, and that is not limited to the general population (Sharma, Volgman, \& Michos, 2020) but also varied markedly by age groups (Bhopal \& Bhopal, 2020). Research that studied risk factors also highlighted the importance of age, sex, and some specific comorbidities (Caramelo, Ferreira, \& Oliveiros, 2020). Almost all research highlighted the higher impact of Covid-19 mortality in males compared to females (Gebhard, RegitzZagrosek, Neuhauser, Morgan, \& Klein, 2020), but this is mainly related to the absolute numbers or crude indicators. Research that analyze excess mortality due to Covid-19 has shown that discrepancies between sexes were not so apparent marked (Kontis, Bennett, Rashid, \& al., 2020). Also, a higher risk of death among people aged 65+ years (Yanez, Weiss, Romand, \& Treggiari, 2020) was revealed. It is essential to mention that all this Covid-19 associated mortality were observed in almost all countries.

\section{Methods and data}

This research is focused on the Covid-19 associated deaths until October 14, 2021. The first Covid-19 death was registered on the territory of Moldova on March 18, 2020. In the period March 18, 2020, and October 14, 2021, 7137 deaths were reported. In this research, we analyse just 7054 deaths.

Deaths are collected from the official page of the Ministry of Health of the Republic of Moldova (Ministry). On the official page of the Ministry the data on the Covid-19 associated deaths by day of death, sex, age, district where the 
person lived, another existent comorbidities and place of death are available. The information about the age, sex and district where a person had lived present the most interest.

Five-year age intervals were used to avoid errors caused by the distribution of deaths over one-year age intervals. This avoids errors caused by small numbers, especially at a young age or at a very old age.

Out of the total 7137 deaths, 7054 deaths were analyzed in this research. Thus, 83 deaths were excluded due to incomplete information. Incomplete information was considered the lack of sex, the lack of age, or the district of residence of the person.

\section{Results and discussions}

As of October 14, 2021, 7137 positive Covid-19 deaths were registered in Moldova. We remind recall that the first death in the country was reported on March 18, 2020. The case fatality rate at the national level on October 14, 2021, was 22,8 deaths per 1000 cases of infection. This indicator is slightly higher than a year ago (Pahomii, 2020).

Throughout the period, the responsible actors tried to implement various measures to reduce the impact of Covid-19 on the population health, but also on the healthcare system general medical system. The efficiency of the measures taken by the Government is not the goal of this paper, for which a deeper analys is needed. We must mention that despite these measures, Moldova is among the countries with a very difficult epidemiological situation. However, between June and July, an improvement in the epidemiological situation was observed, which also positively affected the Covid-19 associated mortality (Fig. 1).

The data presented in Figure 1 clearly shows the waves of increase in the number of Covid-19 positive deaths. Thus, after a significant reduction in the number of deaths (June-July), accompanied by a period of easing of restriction measures on Covid-19 pandemic, followed by period of increase of the number of deaths, which outlines the next pandemic wave. This evidence is demonstrated mainly by the Response Index presented by the WHO (World Health Organization) - Stringency Index (World Health Organization, 2021). 


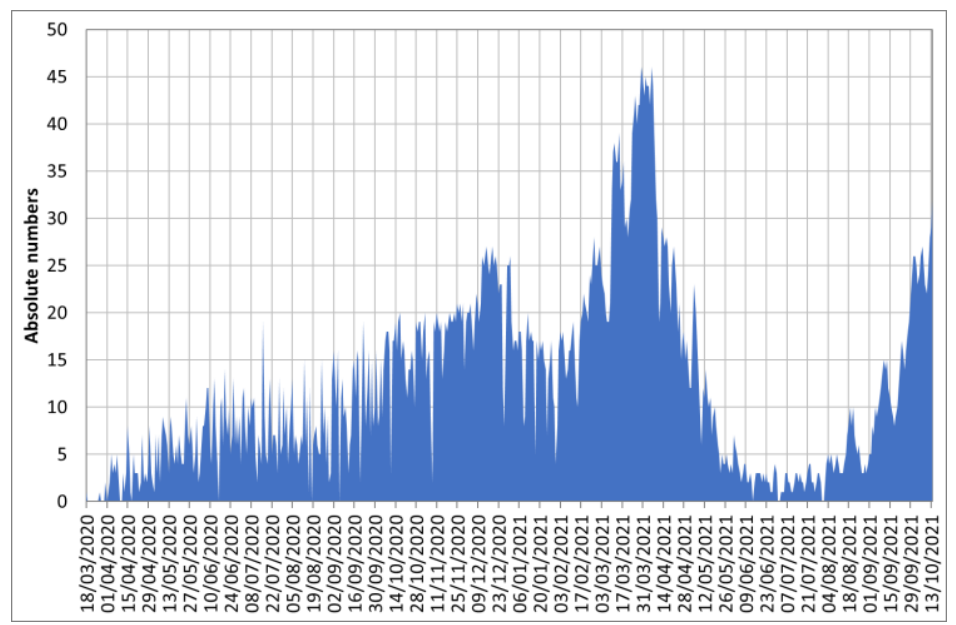

Figure 1. Daily reported Covid-19 deaths, absolute numbers Source: Author's calculations.

In addition to the evolution of the number of deaths, the distribution of these deaths by sex and age is much more important (Fig. 2). The analysis of deaths included in this research shows that $52.1 \%$ of the deaths are among women and $47.9 \%$ among men. For the most part, the number of deaths for both women and men is very similar in all age groups except the 80-84 age group, where the deaths among women exceed the deaths among men by 1.5 times. In general, this situation does not repeat the pattern of general mortality, where we have higher mortality among older women and higher male mortality in middle ages. What is typical for Covid-19-associated mortality and overall mortality is the fairly high level of premature mortality. This fact has been highlighted in previous research (Pahomii, 2020). Thus, $52.8 \%$ of the total deaths recorded among women were concentrated until the age of 70, while for men the share of Covid-19 positive deaths is $56 \%$. This is primarily determined by the related health problems of the population. However, the analysis of the number of comorbidities registered among the deceased persons showed that ae person had 2.2 comorbidities on average. 


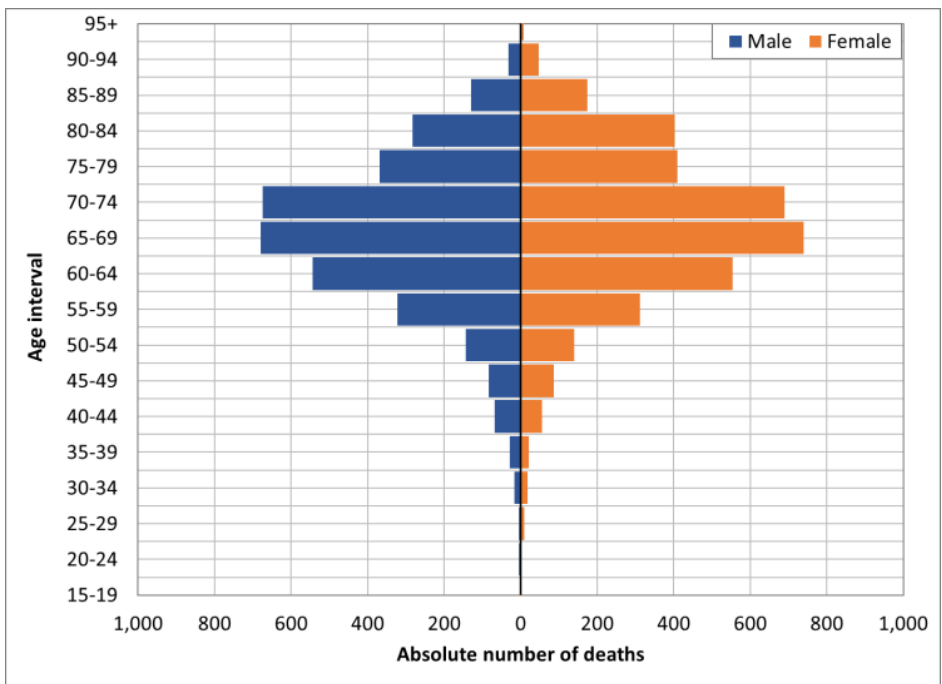

\section{Figure 2. Distribution of the absolute number of Covid-19 positive deaths by sex and age group}

Source: Author's calculations.

Another important aspect in the distribution of Covid-19 associated deaths is the regional aspect. Approximately one-third of the total registered deaths are in Chisinau municipality, followed by the North region with about a quarter of the total registered deaths, the Center region with just over $20 \%$, followed by the South region and the Transnistrian region (Fig. 3). The number of deaths per region is largely determined by both the number of the population and the population density. This situation is much more eloquent in the case of Chisinau, where a large population is concentrated on a relatively small territory, which determines direct proximity of people, so higher level of infection of Covid-19 and a higher risk of death.

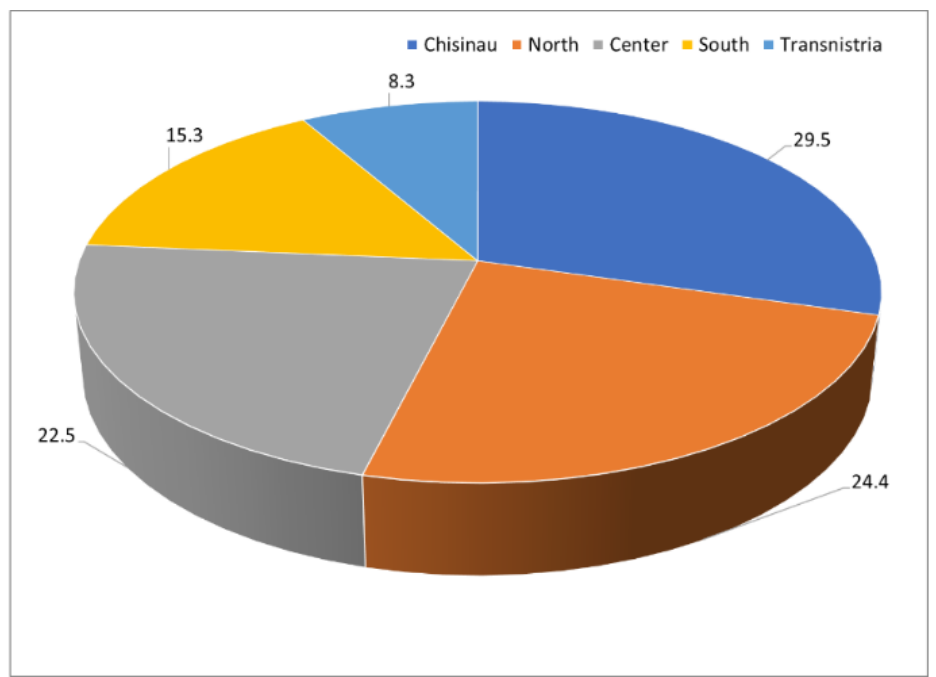

Figure 3. Share of registered Covid-19 deaths by regions

Source: Author's calculations. 
The larger municipalities within the analyzed regions also had a higher proportion of deaths compared to other territorial-administrative units within the regions.

It is essential to mention that in regions is observed a different level of premature Covid-19 associated mortality (Table 1). However, data must be interpreted with care. Their accuracy can be affected by low numbers and other factors linked with registration. Available at the moment of research, data have shown that the level of premature mortality differs up to 8 p.p. between regions. The most different situation is registered for Transnistria, but these data due to a low number of observations (587 Covid-19 associated deaths) are influenced by the „Law of small numbers”.

Some uncommon was observed for the level of premature mortality in the female population from the Centre region. The highest level of premature mortality for both age-threshold was observed among females. This fact demonstrated that something, in this case, went wrong. The premature mortality among males is characteristic for all societies. This situation can be explained by some problems with registering deaths in the Dubasari district, which belongs to two different regions. One part of this district belongs to the Centre region, and the other one belongs to the Transnistria jurisdiction.

Table 1 presents two appropriate age thresholds to highlight in which age group the most of the registered deaths are concentrated. So, the differences between the cumulative value of these two age groups are are approximately $20 \%$, which means that the highest share of premature Covid19 associate mortality is concentrated in the age-group 65-69 years.

Table 1. Share of premature mortality in total Covid-19 associated mortality per region and different age-threshold

\begin{tabular}{|c|c|c|c|}
\hline & Male & Female & Total \\
\hline \multicolumn{4}{|c|}{ Up to 65 years } \\
\hline Chisinau & 34.5 & 28.5 & 31.5 \\
\hline North & 36.1 & 32.1 & 34.0 \\
\hline Centre & 35.8 & 37.7 & 36.8 \\
\hline South & 40.7 & 37.4 & 39.0 \\
\hline Transnistria & 30.4 & 26.4 & 28.1 \\
\hline \multicolumn{4}{|c|}{ Up to 70 years } \\
\hline Chisinau & 54.3 & 49.4 & 51.9 \\
\hline North & 55.8 & 51.6 & 53.5 \\
\hline Centre & 58.4 & 60.7 & 59.6 \\
\hline South & 60.5 & 56.6 & 58.4 \\
\hline Transnistria & 46.4 & 40.1 & 42.8 \\
\hline
\end{tabular}

Source: Author's calculations.

It is important to highlight that despite the higher number of registered deaths in Chisinau, premature mortality is lower in the region if we exclude Transnistria. This fact indicates some different age patterns of the Covid-19 
associated mortality in Chisinau compared with other regions. Two different factors can explain it. One crucial factor is the age structure of the population in regions. Another important factor is determined by the highest access of the population from Chisinau to healthcare compared with other regions.

\section{Conclusions}

In this research, only some aspects related to the Covid-19 associated mortality at a national and sub-national level were highlighted, without making any links or correlations with risk factors or the impact of certain protection measures, including vaccines. We reiterate that the article's purpose was to highlight a general framework and not build certain causeeffect links. This was not possible mainly because it required the existence of a much deeper information base, which is largely lacking at the moment. Thus, one of the central moments, otherwise specific for most countries, remains the availability of qualitative data at the detailed possible level of disaggregation. However, the effort of the Ministry in publishing data on daily deaths and the details presented should also be highlighted. However, the analysis of the absolute number of deaths is one of the most rigid types of research. The absolute numbers were being exposed to an accumulation of errors; because of that the obtained data must be interpreted with the most caution.

Also, the present data represent a framework image rather than a general one, the Covid-19 pandemic being in full swing. Considering the evolution of the number of deaths at the end of the analyzed period, a further escalation of the situation will most likely follow.

A rather worrying moment is determined by the rather high share of deaths at relatively young ages, until 65 . However, if the most affected group was the oldest old population in most countries of the world, a relatively younger Covid-19 associated mortality is specific for Moldova. This fact does not reduce the burden of the Covid-19 pandemic, nor does it reduce the loss of human lives, but once again accentuates the population's generally poor health.

Analysis of data has shown the importance of the development of the national medical infrastructure. The fact that the most developed medical infrastructure is concentrated in Chisinau determines the regional discrepancies.

Another important indirect conclusion of the research is the necessity to improve the population's general health, because the greatest number of relatively young Covid-19 associate deaths are determined by the multitude of pre-existing comorbidities. The last but not the least, is the necessity of continuing the implementation of effective protective measures against Covid19. 


\section{REFERENCES}

Bhopal, S. S., \& Bhopal, R. (2020). Sex differential in COVID-19 mortality varies markedly by age. The Lancet, 396(10250), 532-533. doi:https://doi.org/10.1016/S0140-6736(20)31748-7

Caramelo, F., Ferreira, B., \& Oliveiros, B. (2020). Estimation of risk factors for COVID-19 mortality - preliminary results. medRxiv. doi:https://doi.org/10.1101/2020.02.24.20027268

Gebhard, C., Regitz-Zagrosek, V., Neuhauser, H. K., Morgan, R., \& Klein, S. L. (2020). Impact of sex and gender on COVID-19 outcomes in Europe. Biology of sex differences, 11, 1-13. doi:https://doi.org/10.1186/s13293-020-00304-9

Kontis, V., Bennett, J., Rashid, T., \& al., e. (2020). Magnitude, demographics and dynamics of the effect of the first wave of the COVID-19 pandemic on all-cause mortality in 21 industrialized countries. Nature Medicine, 26, 1919-1928. doi:ttps://doi.org/10.1038/s41591-020-1112-0

Pahomii, I. (2020). Regional aspects of COVID-19 mortality in the Republic of Moldova. Economic and social implications of the COVID-19 pandemic: analysis, forecasts and consequences mitigation strategies (pp. 280283). Chisinau: National Institute of Economic Research. Retrieved from

http://dspace.ince.md/jspui/bitstream/123456789/1107/1/Regiona l_aspects_of_COVID-19_mortality_in_the_Republic_of_Moldova.pdf

Sharma, G., Volgman, A. S., \& Michos, E. D. (2020). Sex Differences in Mortality From COVID-19 Pandemic: Are Men Vulnerable and Women Protected? JACC. Case reports, 1407-1410. doi:10.1016/j.jaccas.2020.04.027

World Health Organization. (2021, November). COVID-19 Explorer. Retrieved from World Health Organization Web site: https://worldhealthorg.shinyapps.io/covid/

Yanez, N., Weiss, N., Romand, J., \& Treggiari, M. (2020). COVID-19 mortality risk for older men and women. BMC Public Health, 20, 1742. doi:https://doi.org/10.1186/s12889-020-09826-8 